\title{
Microsatellites and Morphometric Diversity Among Indonesian Local Duck Populations in Lombok Island
}

\author{
Maskur Maskur $^{*}$, Muhammad Muhsinin ${ }^{1}$, Lestari, $^{*}$ Tapaul Rozi ${ }^{1}$, Asnawi $^{2}$ \\ ${ }^{1}$ Laboratory of animal genetics and breeding, Faculty of Animal Science, University of Mataram, Indonesia $;{ }^{2}$ Laboratory \\ of Poultry Production, Faculty of Animal Science, University of Mataram, Indonesia.
}

\begin{abstract}
The genetic diversity of three breeds of Indonesian local duck in Lombok island West Nusa Tenggara province locus was investigated based on morphometric traits and four microsatellites marker. Experimental ducks consisted of 75 Sasak ducks, 75 Khaki Campbell ducks and 70 Mojosari ducks. Morphometric traits were recorded and statistically analyzed, whereas genetic parameters of microsatellite loci were calculated using PopGene32. In this study, the mean PIC of the 4 microsatellite loci in all populations was 0.472 , whereas AY287 was the most polymorphic locus with a PIC value of 0.735 and APL579 was a monomorphic locus with a PIC value of 0 (zero). The mean value of observed heterozygosity (Ho) is lower than expected (He), with the values 0.393 and 0.472 (Khaki Campbell); 0.433 and 0.532 (Mojosari); and 0.330 and 0.451 (Sasak), respectively. This indicates that the population is heading towards a heterozygosity deficit and proves that the three populations are not in Hardy-Weinberg equilibrium. The inbreeding coefficient in the three populations was quite high with a positive Fis value ranging from $0.000-0.422$. Meanwhile, the value of the genetic differentiation index (Fst) in all populations is zero (0), indicating that there is no differentiation between breeds at the observed loci.
\end{abstract}

Keywords | Local duck, Microsatellites, Morphometric, Inbreeding and differentiation

Received | December 02, 2021; Accepted | January 05, 2022; Published | February 15, 2022

*Correspondence | Maskur Maskur, Faculty of Animal Science, University of Mataram, 62 Majapahit Street, Lombok, 81325 West Nusa Tenggara Province, Indonesia; Email: maskur@unram.ac.id

Citation | Maskur M, Muhsinin M, Lestari, Rozi T, Asnawi (2022). Microsatellites and morphometric diversity among Indonesian local duck populations in Lombok island. Adv. Anim. Vet. Sci. 10(3): 694-701.

DOI | http://dx.doi.org/10.17582/journal.aavs/2022/10.3.694.701

ISSN (Online) | 2307-8316

\section{INTRODUCTION}

$\mathrm{I}$ n some countries including Indonesia, the practice of breeding and hybridization is conducted by importing livestock with higher productivity to increase the productivity of local livestock. These practices seem to increase genetic diversity, but the consequences can threaten the existence of some native livestock. The genetic resources of livestock should be viewed as a future insurance, which has important meaning to improve the socio-economic life at present or in the future. Therefore, it is essential to maintain a balance of breeding and hybridization practices with the conservation of the genetic resources of livestock (Oskam et al., 2004).

In Indonesia, there are several commercial duck breeds currently used for meat and egg production for local markets. These local ducks are named according to their location, such as in Java island, there are Tegal duck, Mojosari duck and Magelang ducks; in Bali island, known as balinesse duck; in Lombok island, known as sasaknesse duck and others. Breeders develop local ducks through crosses with imported ducks and produce various hybrids with distinctive morphological characteristics and productivity levels (Hetzel, 1985; Wilson et al., 1997). The enormous genetic diversity of local ducks in Indonesia is the result of breeding practices and production systems developed over time by breeders to fulfill diverse needs in various environmental conditions (Maharani et al., 2017). The availability of wide biodiversity is an important element in the sustainable use of animal genetic resources (AnGR) as it enables livestock keepers to adapt their animals to changing conditions (FAO, 2007). Evaluation of the genetic diversity of ducks is essential for the development and sustainability of production and is very useful for maintaining and exploiting the genetic resources of local ducks. 
Molecular techniques have provided a number of new genetic markers for the study of genetic variation among domestic animals. Among the genetic markers, microsatellites have been comprehensively exploited to access genetic variability as they contribute information on every region of the genome (Sharma et al., 2015) and much clear evidence of the usefulness for genetic diversity studies (Hariyono et al., 2019). In the recent study, microsatellites were recommended as the most appropriate marker choice for the analysis of the diversity and population structure, or study the evolution of related species (Sultana et al., 2017; Seo et al., 2016). Microsatellites are abundant in copy numbers and widely distributed in the genome, codominant and relatively easy to produce and analyze, especially after successfully amplifying these microsatellite loci by PCR technology.

In this paper, we investigated the genetic diversity of 3 local duck population-based on phenotype variability and 4 microsatellite loci as DNA markers. The previous studies in order to analyze the genetic diversity among Indonesian local duck populations have been reported by researchers such as Ismoyowati and Purwantini (2011); Rusfidra et al. (2013); and Maharani et al. (2017). This study was conducted to evaluate the genetic diversity of the Indonesian local duck population on the island of Lombok based on morphometric and microsatellite markers. The results of this study are expected to provide scientific information for designing breeding strategies and conservation plans.

\section{MATERIALS AND METHODS}

All procedures carried out with the use of animals had been approved by the board of ethics committee of Faculty of Animal Science, University of Mataram, Indonesia, with the register number: 05/UN18.F2/EC/2020.

\section{Phenotype traits measurement}

Two hundred and twenty local ducks consisting of 75 Sasak ducks, 75 Khaki Campbell ducks and 70 Mojosari ducks were reared in a semi-open house cages at the Experimental Farm of Animal Science Faculty, University of Mataram. All experimental ducks were given the same feed, namely starter feed (containing 21\% Crude Protein and $2806 \mathrm{kcal} /$ $\mathrm{kg}$ Metabolic Energy) for 1-3 weeks old duck and grower feed (containing 15\% Crude Protein and $2806 \mathrm{kcal} / \mathrm{kg}$ Metabolic Energy) for 4-10 weeks old duck. The observed variables were body weight, average feed conversion, shank length and diameters and middle finger length, feather color, shank and bill color. Morphometry was measured during one week when duck start to production to 10 weeks (Ismoyowati et al., 2006). The data collected were analyzed using an analysis of variance of one-way classification with mathematical models by Gomez and Gomez (1984).

\section{DNA EXTRACTION, PCR AND GENOTYPING}

Blood samples for DNA genotyping were collected approximately $1.0 \mathrm{ml}$ from 220 unrelated individuals representing 3 duck breed populations, including 75 Sasak ducks, 75 Khaki Campbell ducks, and 70 Mojosari ducks. Blood samples were collected on Venoject tube with K2EDTA_ and preserved at $-25^{\circ} \mathrm{C}$ for several weeks. The isolation of genomic DNA from blood samples was performed using the Wizard Genomic kit following manufacturer instructions (Promega, Madison, WI, USA).

The PCR analysis was carried out in eppendorf mastercyclers nexus gradient (Eppendorf-Hamburg, Germany). The reaction mixture was conditioned in a total volume of 25 $\mu \mathrm{l}$ and contained approximately $100 \mathrm{ng}$ of genomic DNA, $0.5 \mu \mathrm{M}$ of each primers (forward and reverse), $1 \times \mathrm{PCR}$ buffer $(10 \mathrm{mM}$ Tris- $\mathrm{HCl} \mathrm{pH} 9.0), 50 \mathrm{mM} \mathrm{KCl}$ and 1.5 $\mathrm{mM} \mathrm{MgCl}, 5 \%$ deionized Formamide, $200 \mu \mathrm{M}$ dNTP, and $0.025 \mathrm{U}$ of Taq polymerase (Pharmacia). The PCR programs were performed in the following cycles: Initial cycle at $94^{\circ} \mathrm{C}$ for 5 minutes followed by 33 cycles $94^{\circ} \mathrm{C}$ for 30 seconds, $60^{\circ} \mathrm{C}$ for 60 seconds, and $72^{\circ} \mathrm{C}$ for 90 seconds, then ended the next step at $72^{\circ} \mathrm{C}$ for 7 minutes. Sequence and annealing temperatures of the primer are presented in Table 1.

Table 1: Sequence and annealing temperatures of the primer (Su and Chen, 2009).

$\begin{array}{lllc}\text { Locus } & \text { Primer sequence }\left(\mathbf{5}^{\prime} \rightarrow \mathbf{3}^{\prime}\right) & \begin{array}{l}\text { Annealing } \\ \text { temperature }\left({ }^{\circ} \mathbf{C}\right)\end{array} & \text { Allele fragment } \\ \text { CADU086 } & \begin{array}{l}\text { F: GCAGAGCGGTGTGAGAGCA } \\ \text { R: AACACAGCTTCACCCCACAG }\end{array} & 60.1 & 175-217 \\ \text { CMO212 } & \begin{array}{l}\text { F: GGATGTTGCCCCACATATTT } \\ \text { R: TTGCCTTGTTTATGA GCCATT }\end{array} & 55.0 & 221-283 \\ \text { APL579 } & \begin{array}{l}\text { F: ATTAGA GCAGGAGTTAGGAGAC } \\ \text { R: GCAA GAA GTGGCTTTTTTC }\end{array} & 55.0 & 159-289 \\ \text { AY287 } & \begin{array}{l}\text { F: TGCAGGTAGGTCTTCTGTTCTG } \\ \text { R: GCCAGTCCTTTGCTTCGTAA }\end{array} & 60.8 & \\ & & & \\ \end{array}$


The amplification products were separated by electrophoresis on $2.5 \%$ agarose and visualized by $\mathrm{EtBr}$ staining. The images data were analyzed using the Image Analysis Software. The position of the DNA band on the agarose gel is determined manually. The size and amount of the allele that appears on the gel are determined on the assumption that all DNA bands with the same migration rate are homologous, whereas the alleles with the fastest migration are defined as allele $\mathrm{A}$, the next is the $\mathrm{B}$ allele and so on (Leung et al., 1993).

The results of calculating genetic parameters were obtained using the Microsatellite-Toolkit software. PopGene software (Version 32) was used to determine effective numbers of alleles $(\mathrm{Ne})$, observed heterozygosity $(\mathrm{Ho})$, expected heterozygosity (He), Shannon's Information Index (I), fixation indeks (Fis) and differentiation indeks (Fst) for data as depicted in Tables 4 and 5.

\section{RESULTS AND DISCUSSION}

\section{PhenotyPe AND MORPHOMETRIC VARIABILITY}

The average body weight of the three ducks breed at weeks 1 to 10 is listed in Table 2. The analysis of variance results showed that the body weight and average daily gain of the Sasak ducks were not significantly different from the Khaki Campbell ducks and were significantly smaller $(\mathrm{P}<$ 0.05) compared to with Mojosari duck. The results of this study showed that the increase in body weight gain in the three breeds of ducks occurred until the age of 5-6 weeks, then growth slowed down the following week. Growth in ducks is generally the fastest in the starter period, then slows down in the next growth period (Rosilawati et al., 2010). In crossbreed ducks (alabio $x$ peking), the highest body weight gain occurred at the age of 6 weeks (Susanti, 2012).

The difference in body weight and average daily gain between the three breeds of ducks indicates the type of production of the ducks. Khaki Campbell ducks and Sasak ducks are true laying ducks, where the characteristics of laying ducks include small bodies (Sugeng et al., 2018), while Mojosari ducks are dual-purpose ducks that produce eggs and produce meat with larger body size. The difference in body weight and average daily gain in this study was due to genetic factors because environmental effects have been made uniformly. Ismoyowati et al. (2006) reported that when the effects of the environment are uniform, phenotypes that appear will show the genetic capability.

Quantitative and qualitative traits such as feather, bill color, shank color, shank length and diameters, and middle finger length were the basis of a selection process and breeding duck. According to Yakubu and Ugbo (2011), comparison of phenotype-based on morphological characteristics could be representing of genetic differences. The results of morphometric traits measurement are listed in Table 3.

Table 2: Average daily gain and feed conversion of 3 breeds Indonesian local duck.

\begin{tabular}{|c|c|c|c|c|}
\hline \multirow[t]{2}{*}{ Breed } & \multicolumn{2}{|c|}{ Average body weight (grams) at age } & \multirow[t]{2}{*}{ Average feed conversion } & \multirow{2}{*}{$\begin{array}{l}\text { Average daily gain } \\
\text { (grams/day) }\end{array}$} \\
\hline & 1 week & 10 weeks & & \\
\hline Sasak & $52.98^{\mathrm{a}}$ & $917.84^{\mathrm{a}}$ & $3.60^{\mathrm{a}}$ & $13.73^{\mathrm{a}}$ \\
\hline Khaki campbell & $62.50^{\mathrm{b}}$ & $907.09^{a}$ & $3.90^{\mathrm{b}}$ & $13.40^{\mathrm{a}}$ \\
\hline Mojosari & $66.30^{\mathrm{b}}$ & $1124.69^{b}$ & $4.04^{\mathrm{b}}$ & $16.80^{c}$ \\
\hline
\end{tabular}

a,b,c Different superscripts within the same column represents a significant difference $(\mathrm{P}<0.05)$.

Table 3: Morphometric and colors of bill, shank and feathers at 10 weeks.

\begin{tabular}{|c|c|c|c|}
\hline Variable & Sasak & Khaki Campbell & Mojosari \\
\hline \multicolumn{4}{|l|}{ Shank and Middle finger } \\
\hline Shank length $(\mathrm{cm})$ & $5.78 \pm 0.56$ & $5.70 \pm 0.53$ & $5.83 \pm 0.59$ \\
\hline Shank diameters $(\mathrm{cm})$ & $1.10 \pm 0.09$ & $1.09 \pm 0.08$ & $1.14 \pm 0.07$ \\
\hline Middle finger length $(\mathrm{cm})$ & $6.72 \pm 0.71$ & $6.52 \pm 0.69$ & $6.53 \pm 0.74$ \\
\hline Posture tubuh & $\begin{array}{l}\text { slightly upright posture, } \\
\text { cylindrical-shaped body and } \\
\text { slender (elevation angle } \pm 45^{\circ} \text { ) }\end{array}$ & $\begin{array}{l}\text { slightly upright posture with a } \\
\text { long and slender neck (elevation } \\
\text { angle } \pm 35^{\circ} \text { ) }\end{array}$ & $\begin{array}{l}\text { the body showed like the bottle, } \\
\text { relatively big and nearly vertical } \\
\text { (elevation angle } \pm 70^{\circ} \text { ) }\end{array}$ \\
\hline \multicolumn{4}{|l|}{ Colors of } \\
\hline Bill & $\begin{array}{l}\text { Black, Black and Chocolate } \\
\text { combination }\end{array}$ & Yellow & Black \\
\hline Shank & Black & Yellow & Light yellow \\
\hline Feathers & $\begin{array}{l}\text { In general, the whole body is } \\
\text { light brown and the tips of the } \\
\text { wings are white flanked by dark } \\
\text { brown/black }\end{array}$ & $\begin{array}{l}\text { The whole body is dominated by } \\
\text { khaki color }\end{array}$ & $\begin{array}{l}\text { The body is striated reddish brown, } \\
\text { while the head, neck and chest are } \\
\text { black and the bottom is whitish }\end{array}$ \\
\hline
\end{tabular}


Table 4: Genic variation statistics for all loci (Nei, 1987).

$\begin{array}{llllllllll}\text { LOCUS } & \mathbf{N} & \mathbf{N a} & \mathbf{N e} & \mathbf{I} & \text { Ho } & \text { He } & \text { Fis } & \text { Fst } & \text { PIC } \\ \text { AY287 } & 220 & 5.000 & 4.355 & 1.532 & 0.641 & 0.773 & 0.169 & 0.000 & 0.735 \\ \text { CMO211 } & 219 & 4.000 & 3.115 & 1.222 & 0.493 & 0.681 & 0.274 & 0.000 & 0.618 \\ \text { CAUDO86 } & 220 & 3.000 & 2.599 & 1.014 & 0.407 & 0.617 & 0.339 & 0.000 & 0.536 \\ \text { APL579 } & 219 & 1.000 & 1.000 & 0.000 & 0.000 & 0.000 & 0.000 & 0.000 & 0.000 \\ \text { Mean } & 219.5 & 3.250 & 2.767 & 0.942 & 0.385 & 0.518 & 0.181 & 0.000 & 0.472\end{array}$

N: Sample size; Na: Observed number of alleles; Ne: Effective number of alleles; I: Shannon's information index; Ho: Observe heterozygosity; He: Expected heterozygosity; PIC: polymorphic information content; Fis: fixation indeks and Fst: differentiation index.

Table 5: Genetic diversity measures in Indonesian duck populations across 4 microsatellite loci.

\begin{tabular}{lllllllllll} 
DUCK & LOCUS & N & Na & Ne & I & Ho & He & HWE & PIC & Fis \\
Khaki Champbell & AY287 & 75 & 5.000 & 3.785 & 1.439 & 0.711 & 0.743 & 0.002 & 0.692 & 0.032 \\
& CMO211 & 75 & 2.000 & 1.923 & 0.673 & 0.480 & 0.482 & 0.943 & 0.364 & 0.000 \\
& CAUD086 & 75 & 3.000 & 2.919 & 1.085 & 0.380 & 0.664 & 0.000 & 0.583 & 0.422 \\
& APL 579 & 73 & 1.000 & 1.000 & 0.000 & 0.000 & 0.000 & 0.000 & 0.000 & 0.000 \\
Mojosari & Mean & 74.5 & 2.750 & 2.407 & 0.799 & 0.393 & 0.472 & 0.236 & 0.410 & 0.114 \\
& AY287 & 70 & 5.000 & 4.879 & 1.597 & 0.627 & 0.803 & 0.002 & 0.762 & 0.211 \\
& CMO211 & 70 & 4.000 & 3.577 & 1.326 & 0.625 & 0.728 & 0.004 & 0.672 & 0.132 \\
& CAUD086 & 70 & 3.000 & 2.438 & 0.980 & 0.480 & 0.596 & 0.000 & 0.516 & 0.186 \\
\hline \multirow{5}{*}{ Sasak } & APL 579 & 70 & 1.000 & 1.000 & 0.000 & 0.000 & 0.000 & 0.000 & 0.000 & 0.000 \\
& Mean & 70.0 & 3.250 & 2.974 & 0.976 & 0.433 & 0.532 & 0.002 & 0.488 & 0.132 \\
& AY287 & 75 & 4.000 & 2.614 & 1.108 & 0.580 & 0.624 & 0.204 & 0.550 & 0.060 \\
& CMO211 & 74 & 3.000 & 2.630 & 1.033 & 0.380 & 0.626 & 0.001 & 0.550 & 0.386 \\
& CAUD086 & 75 & 3.000 & 2.204 & 0.857 & 0.360 & 0.552 & 0.003 & 0.442 & 0.340
\end{tabular}

N: Sample size; Na: Observed number of alleles; Ne: Effective number of alleles; I: Shannon's Information index; Ho: Observe heterozygosity; He: Expected heterozygosity; PIC: polymorphic information content; HWE: Hardy-Weinberg equilibrium; and Fis: fixation index.

In general, the coat color pattern of Mojosari ducks is dominated by a striated-reddish-brown color. However, other colors are also found in the population such as the combination of striated color with white stripes on the neck and chest area. The appearance of color variations is thought to be caused by a recessive color segregation pattern because the chances of emergence are relatively small (Suparyanto, 2003). The color pattern of the Sasak duck tends to be more varied than the Khaki Campbell and Mojosari ducks. In general, the Sasak duck has a light brown color on the whole body and the tips of the wings are white flanked by dark brown/black. However, several researchers also reported that there were several variations in the color of the Sasak duck, such as black-dark brown on the whole body with different variations (Tamzil and Indarsih, 2017). Phenotypic variation is thought to be due to the intensity of unstructured out-crossing, although one of the parental sources comes from one family.

March 2022 | Volume 10 | Issue 3 | Page 697
The shank length and diameters and middle finger length were morphometric traits that reflect the duck's size and height. Data of shank length of Sasak, Khaki Campbell and Mojosari ducks gathered in this study are $5.78 \pm 0.56$ $\mathrm{cm} ; 5.70 \pm 0.53 ; 5.83 \pm 0.59 \mathrm{~cm}$, respectively (Table 3). The score is shorter than those of Tegal duck $(6.79 \pm 0.56$ $\mathrm{cm})$, Magelang ducks $(7.10 \pm 0.51 \mathrm{~cm})$, and Cirebon ducks $(6.55 \pm 0.50 \mathrm{~cm})$ (Setioko et al., 2005), but the same as Damiaking ducks and Turi ducks $(5.88 \pm 0.44 \mathrm{~cm}$ ) (Sofiyana et al., 2003). Therefore, based on the length of the shank, the three breeds of ducks are classified as medium size.

\section{GENETIC PARAMETERS OF MICROSATELLITE LOCI}

In the present study, 4 microsatellite markers were chosen for further analysis of the genetic diversity of 3 breed Indonesian local ducks population. The genetic diversity of the 3 local duck breeds at the 4 microsatellite loci was estimated. A portion of amplification results showed in Figures 1-4. The results of calculating genetic parameters 
(Tables 4 and 5) were obtained using the MicrosatelliteToolkit software. Effective numbers of alleles (Ne), observed heterozygosity (Ho), expected heterozygosity (He), Shannon's Information Index (I), fixation index (Fis) and differentiation index (Fst) were calculated using PopGene32.

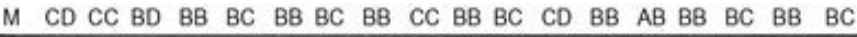

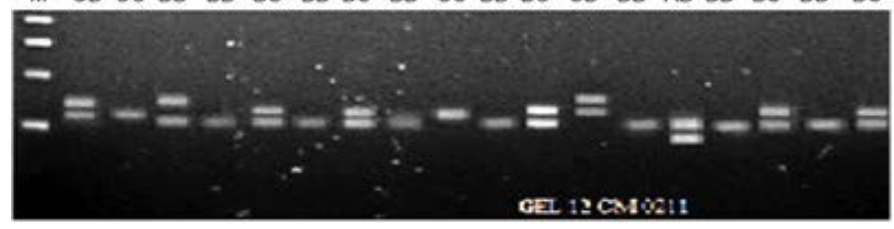

Figure 1: A portion of $\mathrm{PCR}$ result of $\mathrm{CMO} 211$ on agarose gel. $M=100 b p$ marker.

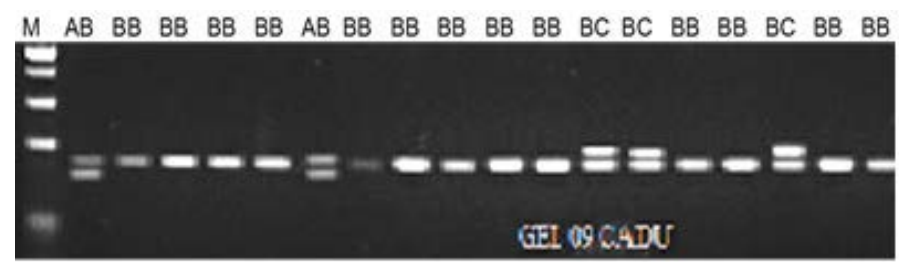

Figure 2: A portion of PCR result of CADU086 on agarose gel. $\mathrm{M}=100 \mathrm{bp}$ marker.

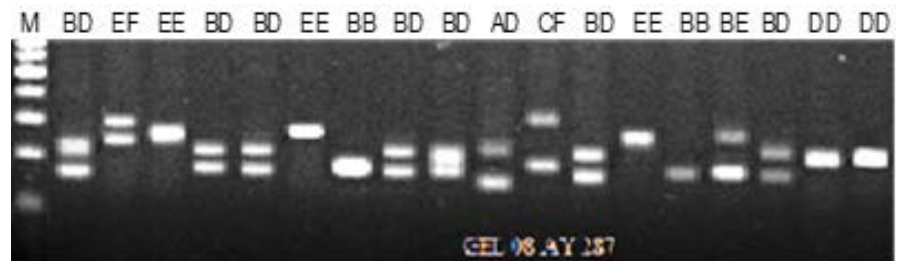

Figure 3: A portion of PCR result of AY287 on agarose gel. $M=100 b p$ marker.

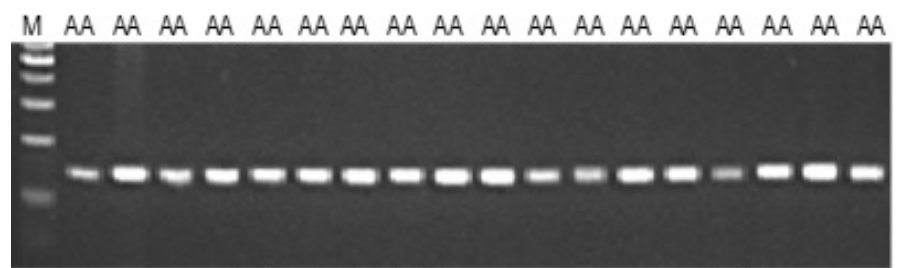

Figure 4: A portion of PCR result of APL579 on agarose gel. $\mathrm{M}=100 \mathrm{bp}$ marker.

The effective number of alleles is the number of equally frequent alleles that would take to achieve the same expected heterozygosity in population and often used to assay the effect of alleles in each population and to reflect the genetic variation expressed by inverse homozygosity. Estimating the value of heterozygosity has an important meaning, namely to get an idea of genetic variability (Marson et al., 2005) and to know the level of polymorphism of an allele and the prospect of the population in the future (Falconer and Macay, 1996). Genetic diversity can be estimated as the average level of heterozygosity in the population, the number of alleles per locus and the percentage of polymorphic loci (Soysal, 2004).
Advances in Animal and Veterinary Sciences

The number of alleles for the 4 microsatellites in the 3 duck breeds analyzed was 13 , with a mean of 3.25 (Table 4). The highest number of alleles was 5 (AY287) and the lowest was 1 (APL579). The mean number of alleles of the four loci in the analyzed population $(\mathrm{Na}=3.25)$ was lower than that of the four breeds of Chinese indigenous layingtype ducks at the same four loci $(\mathrm{Na}=5.25, \mathrm{Su}$ and $\mathrm{Chen}$, 2009). The mean number of alleles of the CAUD086 locus in the 3 analyzed breeds $(\mathrm{Na}=3)$ was also found to be lower than that of the 4 Javanese duck breeds $(\mathrm{Na}=6$, Maharani et al., 2017). According to Barker (1994), microsatellite markers used in genetic distance estimation should have more than four alleles, to reduce standard errors in distance estimation. Meanwhile, according to FAO standards, a minimum of four different alleles per locus is required for the assessment of genetic variation and differences within and between populations. Thus, the 2 microsatellite loci AY287 and CMO211 used in this study showed sufficient polymorphism to evaluate genetic variation within and between local duck populations in Indonesia.

By definition, expected heterozygosity represents the probability that a randomly selected individual from a population in Hardy Weinberg equilibrium is heterozygous, whereas observed heterozygosity indicates the effective proportion of heterozygous individuals at each locus (Carco et al., 2018). The results of measuring the heterozygosity value of each locus in all samples are presented in Table 4. The He value is higher than Ho for 3 polymorphic loci except for APL579 which is a monomorphic locus. The mean value of observed heterozygosity (Ho) and expected heterozygosity $(\mathrm{He})$ in all loci and populations also revealed medium to high genetic diversity, with the values 0.385 and 0.518 , respectively. The expected mean heterozygosity of 0.518 indicates that the genetic diversity is observed in the local duck population on the island of Lombok is the same as the previous study on local ducks on the island of Java reported by Maharani et al. (2017). This moderate genetic diversity is a good substance in determining breeding strategies, especially in small populations.

PIC measures the quantity of information per microsatellite and depends on the number of identified alleles and allele frequency (Purwantini and Purwantini, 2010). Polymorphism Information Content (PIC) is the ability of a genetic marker to detect the polymorphism among individuals of a population, and often used to measure the informativeness of a genetic marker for linkage studies. In this study, the mean PIC of the 4 microsatellite loci in all populations was 0.472 , with 3 microsatellites showing high diversity (Table 4) and 1 locus producing monomorphic for all three races. AY287 is the most polymorphic locus with a PIC value of 0.735 , and APL579 is a monomorphic locus with a PIC value of 0 . Bolstein et al. (1980) classified the 
PIC value as highly informative (PIC $>0.50$ ), reasonably informative $(0.50>\mathrm{PIC}>0.25)$, and slightly informative (PIC < 0.25). Thus, three loci (AY287, CMO211 and CAUDO86) were highly informative loci and could be used for further genetic analysis in the studied population and one locus, APL579, could not be used. The results of this study did not differ from Su and Chen (2009), which included AY287, CAUDO86, CMO211, and APL579 for genetic diversity analysis of Chinese indigenous layingtype ducks. In the study AY287 had the highest PIC (0.695) compared to CAUD086, CMO211 and APL579 at 0.682 , respectively; 0.309 and 0.348 . The APL579 locus was also found as a monomorphic locus ( 1 allele) in Jinding breed ducks with PIC 0 . Analysis conducted by Carco et al. (2018) in the population of Italian and Polish duck breeds, the CAUD086 locus also showed a high PIC value of 0.735 .

\section{GENETIC DIVERSITY WITHIN THE BREEDS}

Genetic diversity among breeds is indicated by the number of alleles, $\mathrm{Ho}, \mathrm{He}$ and PIC values which are basic measures and provide important information for individual and population discrimination (Seo et al., 2016). The results of measuring the value of genetic diversity among the 3 local duck breeds are listed in Table 5. Locus AY287, CAUDO86 and CMO211 showed a wide variation among populations. Different microsatellite loci showed high variation within each population and the same locus also showed high variation between populations. AY287 has the highest observed heterozygosity values for 3 breeds namely 0.711 (Khaki Campbell), 0.627 (Mojosari) and 0.580 (Sasak). Meanwhile, APL579 was found as a monomorphic locus in 3 populations, where there were no heterozygous individuals. Carco et al. (2018) showed the average observed heterozygosity for the Polish population, 0.692 and 0.652 , respectively, while the Italian breeds had lower values: 0.450 for $A G V$ and 0.372 for AMG. Ahmadi et al. (2007) also found similar levels of genetic variation within the Peking and Muscovy populations with values of heterozygosity of 0.530 and 0.440 , respectively.

In our study, the observed heterozygosity for all locus and all population around 0.000 to 0.711 , and the expected heterozygosity was 0.000 to 0.803 . The mean value of observed heterozygosity (Ho) and expected heterozygosity $(\mathrm{He})$ in all loci and each population revealed medium to high genetic diversity, with the value 0.393 and 0.472 (Khaki Campbell); 0.433 and 0.532 (Mojosari); and 0.330 and 0.451 (Sasak), respectively. The mean value of observed heterozygosity obtained in this study is lower than expected, indicating that the population is heading towards a heterozygosity deficit and proving that the three populations are not in Hardy-Weinberg equilibrium (Table 5).
The Hardy-Weinberg equilibrium test (HWE) confirmed that all loci in the three populations deviated significantly, except for the CMO211 locus in Khaki Campbell ducks and AY287 in Sasak ducks. Maharani et al. (2017) also reported heterozygosity deficit and Hardy-Weinberg equilibrium deviation in a population of 4 Javanese duck breeds where the mean value of observed heterozygosity (Ho) and expected heterozygosity $(\mathrm{He})$ in all loci and population were 0.465 and 0.580 , respectively. Several factors can contribute towards a heterozygotes deficit. First, the locus is under selection pressure. Second, inbreeding may be common in the population. Third, the Wahlunds effect because the presence of a population substructure (Nei, 1987; Peter et al., 2007) and genotyping errors are likely due to low sample quality (Morin et al., 2009). In our research, the deviations from HWE suggest that these loci may be under selection pressure and inbreeding occurs at some loci in all populations.

In addition to the HWE test, we also evaluated genetic diversity among populations using the F Wright statistic. Fst is calculated to estimate the proportion of total genetic variation due to differentiation between populations, while Fis provide an explanation in terms of inbreeding coefficients. The individual inbreeding coefficient relative to the subpopulation (Fis) can be positive or negative, while the estimated value of the genetic differentiation index between populations (Fst) is always positive. Wu et al. (2008) reported that when there is no differentiation, the Fst value is 0 and when the alleles between populations are quite different, the Fst value is equal to 1. In our study, the inbreeding coefficient in the three populations was quite high with a positive Fis value ranging from 0.000 0.422 . This indicates the presence of inbreeding and low heterozygosity at this locus. Meanwhile, the value of the genetic differentiation index $(\mathrm{Fst})$ in all populations is zero (0), indicating that there is no differentiation between breeds at the observed loci. These Fst results suggest that there is no gene flow between different breeds and, equivalently, relatively high reproductive isolation within the same breed. In contrast to our study, several reports showed moderate genetic differentiation in duck populations in Java with Fst value $=0.093$ (Maharani et al., 2017), Beijing and Cherry Valley duck, Fst $=0.075$ (Wu et al., 2009), Chinese indigenous laying-type ducks, FST $=0.184(\mathrm{Su}$ and Chen, 2009), and Asia duck, Fst $=0.135$ (Sultana et al., 2016).

In general, in the three populations (breeds) studied, deficits heterozygote and a low to moderate level of inbreeding have been observed. Some of the most likely reasons related to this phenomenon are: (1) uncontrolled mating with an unbalanced sex ratio (male: female), (2) breeders do not have a pedigree record/reference family structure, and (3) selection at the breeder level based on 
the plumage color and morphometric traits to improve the performance of duck production. The use of limited stock of males to mating practices in the population and selection at the phenotypic level resulted in a deficit heterozygote.

\section{CONCLUSIONS AND RECOMMENDATIONS}

Characterization of three local duck breeds using a panel of 4 microsatellites showed an acceptable level of genetic diversity from the perspective of genetic conservation. The analyzed microsatellites had moderate to high PIC values with the number of alleles in accordance with the FAO minimum standard, except for the APL579 locus. The mean value of observed heterozygosity is lower than expected, indicating that the population is heading towards a heterozygosity deficit and inbreeding coefficients of an individual relative to the subpopulations (Fis) obtained in this study was quite high with a positive value in three local duck populations. Therefore, it is necessary to rearrange the breeding system properly to avoid inbreeding depression. The genetic index of population-based on microsatellite data can provide basic information in developing breeding and conservation strategies to protect the germplasm of local Indonesian ducks. However, in the utilization of genetic resources, phenotypic information is also very much needed in relation to efforts to increase productivity. Therefore, the combination of morphometric with microsatellite data will be very necessary for conducting breeding and conservation programs in a sustainable manner.

\section{ACKNOWLEDGMENTS}

Authors thank to Rector University of Mataram for the financial support through the University Research Grand with the contract number: 752U/UN18/LPPM.

\section{NOVELTY STATEMENT}

The previous research to analyze the genetic diversity of Indonesian local ducks has been carried out, especially on the islands of Java and Sumatra. However, local ducks on the Lombok island have specific characteristics and to the best of our knowledge, no studies have been reported on microsatellites and morphometric diversity of local ducks on the Lombok island.

\section{AUTHOR'S CONTRIBUTION}

All authors contributed equally.

\section{CONFLICT OF INTEREST}

The authors have declared no conflict of interest.

\section{REFERENCES}

Ahmadi AK, Rahimi G, Vafaei A, Sayyazadeh H (2007). Microsatellite analysis of genetic diversity in pekin (Anas platyrhynchos) and muscovy (Cairina moschata) duck populations. Int. J. Poult Sci., 6: 378-382. https://doi. org/10.3923/ijps.2007.378.382

Barker JSF (1994). A global protocol for determining genetic distances among domestic livestock breeds. Proceedings of the $5^{\text {th }}$ World Congress on Genetics Applied to Livestock Production; August 7-12; Ontario: University Guelph.

Bolstein D, White RL, Skolnik M, Davis RW (1980). Construction of a genetic linkage map in man using restriction fragment length polymorphisms. Am. J. Hum. Genet., 32: 314-331.

Carcò G, Grajewski B, Cassandro M, Lisowski M, Szwaczkowski $\mathrm{T}$ (2018). Genetic variability of some Italian and Polish duck breeds. Ital. J. Anim. Sci., 17(4): 899-906. https://doi. org/10.1080/1828051X.2018.1436006

Falconer DS and Mackay TFC (1996). Introduction to quantitative genetics. $4^{\text {th }}$ Edition, Addison Wesley Longman, Harlow.

FAO (2007). Status of animal genetic resources. In: The state of the world's animal genetic resources for food and agriculture (Ed. B. Rischkowsky and D. Pilling). Commission on Genetic Resources for Food and Agriculture, Rome, Italy.

Gomez KA and Gomez AA (1984). Procedure statistics for agricultural research. $2^{\text {nd }} \mathrm{Ed}$.

Hariyono DNH, Maharani D, Cho S, Manjula P, Seo D, Choi N, Sidadolog JHP, Lee JH (2019). Genetic diversity and phylogenetic relationship analyzed by microsatellite markers in eight Indonesian local duck populations. AsianAustral.J.Anim. Sci., 32(1): 31-37.https://doi.org/10.5713/ ajas.18.0055

Hetzel DJS (1985). Duck breeding strategies the Indonesian example. In: Farrel d Stapleton P. (Eds). Duck Production Science and World Practice. University of New England: pp. 204-223.

Ismoyowati and Purwantini D (2011). Genetic variability of Bali and Alabio ducks on the basis of phenotypic and microsatellites. Asian J. Poult. Sci., 5: 107-115. https://doi. org/10.3923/ajpsaj.2011.107.115

Ismoyowati, Yuwanta T, Sidadolog JPH, Keman S (2006). Relationship between morphological characteristics and reproductive performance of Tegal duck as the basis selection. J. Indonesian Trop. Anim. Agric., 31(3): 152-156.

Leung H, Nelson RJ, Leach JE (1993). Population structure of plant pathogenic fungi and bacteria. Adv. Plant Pathol., 10: 157-205.

Maharani D, Hariyono DNH, Cho S, Manjula P, Seo D, Choi N, Sidadolog JHP, Lee JH (2017). Genetic diversity among Indonesian local duck populations in Java Island assessed by microsatellite markers. J. Anim. Breed. Genom., 1(2): 136142.

Marson EP, Ferraz JBS, Meirelles FV, Balieiro JCC, Eler J, Figueiredo LGG, Mourão GB (2005). Genetic characterization of European-Zebu composite bovine using RFLP markers. Genet. Mol. Res., 4(3): 496-505.

Morin PA, Leduc RG, Archer FI, Martien KK, Huebinger R, 
Bickham JW, Taylor BL (2009). Significant deviations from Hardy-Weinberg equilibrium caused by low levels of microsatellite genotyping errors. Mol. Ecol. Res., 9: 498504. https://doi.org/10.1111/j.1755-0998.2008.02502.x

Nei M (1987). Molecular evolutionary genetics. Columbia University Press, New York, USA. https://doi.org/10.7312/ nei-92038

Oskam A, Burrell A, Temel T, van Berkum S, Longworth N. ve Vilchez IM (2004). Turkey in the european union, consequences for agriculture, food, rural areas and structural policy. Rural Areas Structural Policy. Final Report. Wageningen University. https://doi. org/10.1079/9780851990941.0127

Peter C, Bruford M, Perez T, Dalamitra S, Hewitt G, Erhardt G (2007). Genetic diversity and subdivision of 57 European and Middle-Eastern sheep breeds. Anim. Genet., 38: 37-44. https://doi.org/10.1111/j.1365-2052.2007.01561.x

Prasetyo S, Lestari, Jan R, Rozi T, Kasip LM (2018). Body growth of sasak ducks and other non original lombok ducks in centre lombok. Indonesian J. Anim. Sci. Tech., 4(1): 181190. https://doi.org/10.29303/jitpi.v3i1.29

Purwantini I, Purwantini D (2010). An estimation of genetic variation in Indonesian local duck using microsatellite markers. Asian J. Poult. Sci., 4: 198-204. https://doi. org/10.3923/ajpsaj.2010.198.204

Rositawati I, Saiful N, Muharlien (2010). Upaya peningkatan performa itik mojosari periode starter melalui penambahan temulawak pada pakan. J. Ternak Tropika, 11(2): 32-40.

Rusfidra, Heryandi Y, Jamsari, Rahman EY (2013). Variasi genetik Itik Bayang berbasis marka mikrosatelit pada lokus AY287 dan lokus AY283. Sains Peternakan, 11: 91-98. https://doi.org/10.20961/sainspet.11.2.91-98

Seo D, Bhuiyan MSA, Sultana H, Heo JM, Lee JH (2016). Genetic divesity analysis of South and East Asian duck populations using highly polymorphic microsatellite markers. Asian Aust. J. Anim. Sci., 29: 471-478. https://doi. org/10.5713/ajas.15.0915

Setioko AR, Prasetyo LH, Bramantiyo B, Purba M (2001). Koleksi dan karakterisasi sifat-sifat beberapa jenis itik. Balai Penelitian Ternak Ciawi. Bogor.

Sharma R, Kishore A, Mukesh M, Ahlawat S, Maitra A, Pandey AK, Tantia MS (2015). Genetic diversity and relationship of Indian cattle inferred from microsatellite and mitochondrial DNA markers. BMC Genet., pp. 16-73. https://doi. org/10.1186/s12863-015-0221-0

Sofiyana S, Setiok AR, Yusnandar ME (2003). Identifikasi Sifat-sifat Kualitatif dan Ukuran Tubuh pada Itik Tegal,
Itik Magelang, dan Itik Damiaking. Proseeding Lokakarya Nasional, Hal, pp. 123-130.

Soysal M (2004). Understanding genetic variation. Regional capacity building training workshop on the conservation and management of animal genetic resources 10-13 May 2004. Department of Animal Science Faculty of Agriculture ,Trakya University,Tekirda_Turkiye,

Sugeng P, Lestari, Rahma Jan, Tapaul Rozi, LM Kasip (2018). Body Growth of Sasak Ducks and Other Non-Original Lombok Ducks in Centre Lombok. Ind.J. Anim. Sci. Tech. Vol. 4 (1): 181-190.

$\mathrm{Su}$ Y, Chen GH (2009). DNA microsatellite analysis of genetic diversity among Chinese indigenous laying-type ducks (Anas platyrhynchos). Czech J. Anim. Sci., 54: 128-135. https://doi.org/10.17221/1675-CJAS

Sultana H, Seo DW, Bhuiyan MSA, Choi NR, Hoque MR, Heo KN, Lee JH (2016). Genetic diversity and phylogenetic analysis of south-east asian duck population based on the mtdna D-loop sequences. J. Anim. Sci., 29(12): 1688-1695. https://doi.org/10.5713/ajas.15.1017

Suparyanto A (2003). Karakteristik itik Mojosari putib dan peluang pengembangan sebagai itik pedaging komersial. Wartazoa, 13(4): 143-150.

Susanti T, RR Noor, PS Hardjosworo, LH Prasetyo (2012). Relationship of molting trait and egg production on crossbred Peking and Alabio ducks. JITV 17(2): 112-119.

Tamzil MH, Indarsih B (2017). Measurement of phenotype characteristics of sasak ducks: Indian runner ducks of Lombok Island Indonesia. Anim. Prod., 19(1): 13-19. https://doi.org/10.20884/1.jap.2017.19.1.553

Wilson BJ, Martin DM, Nott H (1997). Future genetic improvement in pekin type duck. Proceedings $11^{\text {th }}$ European Symposium on Waterfowl, (ESW'97), Nantes, France, pp. 328-334.

Wu F, Huang Y, Ma Y, Hu S, Hao J, Li N (2009). Evaluation of genetic diversity and relationships within and between two breeds of duck based on microsatellite markers. Prog. Natl. Sci., 19: 1581-1586. https://doi.org/10.1016/j. pnsc.2009.06.008

Wu Y, Liu X, Hou S, Huang W (2008). Study on genetic diversity of six duck populations with microsatellite DNA. Asian-Aust. J. Anim. Sci., 21(6): 776-783. https://doi. org/10.5713/ajas.2008.70367

Yakubu, Ugbo SB (2011). An assessment of biodiversity in morphological traits of muscovy ducks in Nigeria using discriminant analysis. Int. Conf. Biol. Environ. Chem., 1: 389-391. 